Akreditasi Ristekdikti,

No: 21/E/KPT/2018 (Sinta 4)

Paradigma,

DOI: https://doi.org/10.31294p.v23i1.9884

Vol. 23, No. 1 Maret 2021

P-ISSN 1410-5063, E-ISSN: 2579-3500

\title{
Penentuan Pola Penjualan Media Edukasi dengan Menggunakan Metode Algoritme Apriori dan FP-Growth
}

\author{
Rizal Rachman \\ Universitas Adhirajasa Reswara Sanjaya \\ e-mail: rizalkhaizuran@gmail.com
}

\begin{abstract}
Abstrak - Cerdas-Sehat Online Shop adalah toko online yang menjual produk dari PT. Tigaraksa bertujuan memasarkan media edukasi. Semua penjualannya bertujuan untuk meningkatkan kecerdasan potensi anak dengan ilmu pengetahuan dan keahliannya serta belajar lebih menyenangkan melalui buku-buku yang dapat mengeluarkan suara dan bisa bernyanyi. Selama ini Cerdas-Sehat Online Shop telah melayani sekian banyak transaksi pesanan produk-produk media edukasi. Semua data aktifitas transaksi disimpan dalam sistem database dengan menggunakan sistem aplikasi berbasis web. Datanya banyak yang belum bisa menemukan tentang trend produk apa aja yang sekarang naik atau turun. Hal tersebut disebabkan karena kurangnya pengetahuan dalam menganalisa produk yang sering laku dalam waktu bersamaan atau dalam satu transaksi dari para pelanggan. Salah satu strategi penjualan yang dapat dilakukan menggunakan disiplin ilmu data mining untuk memperoleh informasi paket penjualan dari data yang banyak dalam waktu cepat. Penyusunan pola pembelian barang yang biasa digunakan dalam data mining dengan algoritme association rule, algoritme yang digunakan menggunakan Apriori dan FPGrowth. Algortime Apriori menghasilkan 5 pola aturan asosiasi minimum support sebesar 10\% dan minimum confidence sebesar 50\% menghasilkan nilai confidence tertinggi yaitu 100\%, sedangkan algoritme FP- Growth menghasilkan 5 pola aturan asosiasi dengan minimum support count 2 menghasilkan nilai support count tertinggi yaitu 8. Dengan menggunakan 2 atribut yaitu no.order dan kode produk dapat menemukan kecenderungan pola kombinasi antar itemset sehingga dapat dijadikan informasi yang sangat penting dalam pengambilan keputusan yang berguna untuk mempersiapkan jenis stok barang apa yang diperlukan kedepanya bagi penjualan di CerdasSehat Online Shop.
\end{abstract}

Kata Kunci-Penjualan, Data Mining, Association Rule, Apriori, dan FP-Growth

\begin{abstract}
Cerdas-Sehat Online Shop is an online shop that sells products from PT. Tigaraksa aims to market educational media. All sales are aimed at increasing the potential intelligence of children with knowledge and expertise and learning more fun through books that can make a sound and can sing. So far, Smart-Sehat Online Shop has served many orders for educational media products. All transaction activity data is stored in a database system using a web-based application system. Many data have not been able to find out which product trends are currently up or down. This is due to a lack of knowledge in analyzing products that often sell well at the same time or in one transaction from customers. One sales strategy that can be done is using data mining disciplines to obtain information on sales packages from large amounts of data in a short time. The arrangement of purchasing patterns for goods commonly used in data mining is the association rule algorithm, the algorithm used is Apriori and FP-Growth. Algortime Apriori produces 5 patterns of association rules with a minimum support of $10 \%$ and a minimum confidence of 50\% resulting in the highest confidence value of 100\%, while the FP-Growth algorithm produces 5 patterns of association rules with a minimum support count 2 resulting in the highest support count value of 8 . With using 2 attributes, namely the order number and the product code, can find the trend of the combination pattern between itemset so that it can be used as very important information in making decisions that are useful for preparing what types of stock items are needed in the future for sales in Smart-Healthy Online Shop.
\end{abstract}

Keywords — Sales, Data Mining, Association Rule, Apriori, and FP-Growth

\section{PENDAHULUAN}

Cerdas-sehat online shop adalah toko online yang menjual produk dari PT. Tigaraksa Tbk. yang mempunyai tujuan menjual media edukasi Smart Family. Selama proses penjualan hanya mengikuti dari kantor pusat dan cenderung tidak berani menyediakan dan menjual barang secara mandiri, karena tidak tahu cara untuk memperkirakan trend produk yang laku dipasaran. Maka dari dibutuhkan aturan-aturan yang dapat membantu dalam pengambilan keputusan yang berhubungan dengan persediaan dan penjualan barang. Salah satu strategi penjualan yang dapat dilakukan yaitu penggunaan disiplin ilmu data mining untuk menganalisa data supaya memperoleh informasi data yang banyak dalam waktu cepat (Zurada, 2019). Tipe data mining yang cocok dalam penentuan banyaknya produk yang 
sering terjual secara bersamaan dalam satu transaksi yaitu association rule (Yanson, 2016). Algoritme association rule yang banyak digunakan adalah algoritme Apriori dan FP-Growth (Faisal, 2018).

Data mining mewakili seluruh teknologi yang berawal dari banyak disiplin ilmu seperti matematika, statistik, ilmu komputer, fisika, teknik, biologi, dan lain-lain, serta beragam aplikasi yang berbeda seperti pada bidang bisnis, kesehatan, sains, dan teknik, dan lain-lain. Pada dasarnya, data mining dapat dilihat sebagai ilmu yang dapat mengelola dataset untuk memberikan informasi yang bermanfaat yang sebelumnya tidak diketahui c.

Aturan asosiasi benar-benar tidak berbeda dari aturan klasifikasi kecuali bahwa dapat memprediksi atribut apa pun, tidak hanya kelas dan ini memberi kebebasan untuk memprediksi kombinasi atribut. Aturan asosiasi tidak dimaksudkan untuk digunakan bersama sebagai satu dataset, sebagaimana aturan klasifikasi. Aturan asosiasi yang berbeda menyatakan keteraturan yang berbeda yang mendasari dataset dan umumnya memprediksi hal yang berbeda. Karena begitu banyak aturan asosiasi yang berbeda dapat diturunkan bahkan dari dataset kecil. Bunga dibatasi untuk yang berlaku untuk jumlah yang cukup besar dan memiliki akurasi yang cukup tinggi pada yang diterapkan. Cakupan aturan asosiasi adalah jumlah keadaan yang diprediksinya dengan benar ini sering disebut dukungan. Keakuratannya sering disebut kepercayaan diri adalah jumlah yang diprediksi dengan benar dinyatakan sebagai proporsi dari semua yang berlaku (Witten, Frank, \& Hall, 2019) .

Algoritme Apriori untuk menemukan semua itemset yang memiliki dukungan tidak kurang dari beberapa menit. Dukungan untuk itemset adalah rasio jumlah transaksi yang mengandung itemset dengan jumlah total transaksi. Itemset yang memenuhi batasan dukungan minimum disebut frequent itemset. Apriori dikarakteristikkan sebagai algoritme pencarian lengkap level bijaksana (pencarian luas pertamanya) menggunakan properti anti monotonisitas itemset : "Jika suatu itemset tidak sering, supersetnya tidak pernah sering," yang juga disebut properti penutupan ke bawah. Algoritme membuat beberapa melewati data. Pada posisi pertama, dukungan itemset individual dihitung dan itemset yang sering ditentukan. Dalam setiap operan berikutnya, seperangkat itemset yang ditemukan sering pada posisi sebelumnya digunakan untuk menghasilkan itemset baru yang berpotensi yang disebut kandidat itemset dan dukungan aktualnya dihitung selama posisi data bagian atas. Pada akhir posisi batasan dukungan minimum yang sudah memenuhi akan dikumpulkan yaitu itemset yang sering ditentukan dan menjadi awal untuk posisi berikutnya. Proses ini diulangi hingga tidak ada itemset baru yang sering ditemukan c

Algoritme FP-Growth menyediakan cara alternatif untuk menghitung itemset yang sering dilakukan dengan meringkas catatan transaksi menggunakan struktur data grafik khusus yang disebut FP-Tree. FPTree dapat dianggap sebagai transformasi dataset ke dalam format grafik. Pendekatan yang menghasilkan dan menguji digunakan dalam algoritme Apriori, FPGrowth pertama-tama menghasilkan FP-Tree dan menggunakan pohon yang sering muncul untuk menghasilkan itemset yang sering. Efisiensi dari algoritme FP-Growth tergantung pada seberapa banyak pengurangan yang dapat dicapai dalam menghasilkan FP-Tree (Chauhan \& Kaur, 2017).

Penjualan merupakan aktifitas pemindahan kepemilikan atas barang atau jasa yang tersedia untuk dijual kepada konsumen. Hal yang sangat penting dalam menentukan sukses tidaknya penjualan sehingga diperlukan suatu strategi yang terencana dalam menempatkan penjualan dalam suatu wilayah. Tujuan utamanya adalah agar benar-benar dapat berhasil menguasai pasar wilayah. Kesalahan dalam menempatkan penjualan dan pembagian wilayah kerjanya akan berdampak pada pembengkakan cost per sales dan efektifitas kerja harian sales yang akhirnya berdampak pada penyebaran dan penjualan produk yang dipasarkan (Bee, 2015).

(Harianto \& Eddy,2016) dengan metode Apriori dan FP-Growth mengambil objek Retail online transaksi data penjualan pada tahun 2011 menghasilkan Algoritme Apriori menghasilkan 39\% sedangkan algoritme FP-Growth menghasilkan 61\% Artinya algoritme Apriori membutuhkan waktu yang lebih sedikit untuk me- nampilkan hasil rules sedangkan FP-Growth membutuhkan waktu yang lebih lama 0.0226 detik dibandingkan algoritme Apriori.

(Henando, 2019) menggunakan algoritme Apriori dan FP-Growth mengambil objek penjualan laptop berbasis website di Indocomputer Payakumbuh menghasilkan algoritme Apriori dan FP-Growth bisa menghasilkan informasi eksekutif dan sistem digunakan untuk mengilustrasikan proses yang berkaitan dan penentuan merk Laptop yang laku di pasaran, hasil nilai support $70 \%$ dan nilai confidence yang cukup tinggi sebesar $70 \%$, bisa dimanfaatkan dalam pengambilan keputusan.

(Putra \& Habibi,2019) menggunakan algoritme Apriori dan FP-Growth mengambil objek data transaksi penjualan online di rumah warna menghasilkan Hasil kombinasi antar item dari perhitungan algoritma Apriori dan FP-Growth yang memiliki nilai support dan confidence paling besar yaitu support $43 \%$ dan confidence $74 \%$. Dengan minimum support $10 \%$ dan minimum confidence $50 \%$ menghasilkan 6 aturan asosiasi pada algoritma Apriori dan FP-Growth.

(Anggraeni, Iha, Erawati, \& Khairunnas,2019) mengambil objek PT. Panca Putra Solusindo Jakarta berbasis website pada Januari sampai Desember 2016 dengan metode algoritme Apriori dan FP-Growth menghasilkan Nilai kepercayaan sebuah produk pada Algoritme Apriori bernilai 92\% dan dapat mengetahui yang dijual suatu waktu, dan algoritme FP-Growth menghasilkan beberapa aturan yang 
memiliki nilai paling banyak, dan untuk mengetahui di masa depan dalam perencanaan strategi penjualan. (Chailes, Hermawan, \& Kurnaedi, 2020) mengambil objek Mukara Online shop di Tangerang menghasilkan transaksi dengan minimal support 0,2 atau $20 \%$ dan minimal confidence 0,1 atau $10 \%$ adalah produk Mie Telur dengan Kecap, produk Kecap dengan Bihun, produk Bihun dengan Kecap. Kesimpulan nya Jadi, Jika pembeli membeli Mie Telur, maka kemungkinan $81.5 \%$ untuk membeli Kecap. Jika pembeli membeli produk Kecap, maka kemungkinan $82.6 \%$ untuk membeli Bihun. Jika pembeli membeli produk Bihun, maka kemungkinan 92.7\% untuk membeli Kecap.

(Junianto \& Rachman, 2020) mengambil objek media edukasi Oisha SmartKids menghasilkan nilai minimum support $25 \%$, nilai minimum confidence $90 \%$ dan pola kombinasi produk dan rules sebesar $100 \%$. Selanjutnya dilengkapi dengan algortma FPtree menghasilkan 10 produk best seller melalui tahap filterisasi dan menemukan pola kombinasi produk.

\section{METODOLOGI PENELITIAN}

Penelitian ini dilakukan dengan proses data mining KDD (Knowledge Discovery In Databases) menggunakan aturan-aturan algoritme Apriori dan FP-Growth pada dataset yaitu data transaksi penjualan pada Cerdas-Sehat Online Shop. Berikut tahapan-tahapan proses data mining menggunakan KDD (Knowledge Discovery In Databases) yaitu :

1. Persiapan awal

Melakukan studi pustaka mengenai hal-hal yang terkait permasalahan data penjualan di online shop.

2. Pemilihan data

Data transaksi penjualan sebanyak 498 transaksi selama 9 bulan yaitu bulan januari-september 2020.

3. Praproses data

Meliputi pembersihan data dari 37 atribut menjadi 2 atribut yaitu no.order dan nama produk.

4. Transformasi data

Konversi representasi data sehingga sesuai dengan spesifikasi format data dibantu dengan Microsoft Excel.

5. Data Modeling

Menggunakan asosiasi algortime Apriori dan FPGrowth

6. Evaluasi

Dibandingkan dengan aplikasi Rapidminer 9.6

7. Penggunaan pengetahuan

Membrikan solusi dan kontribusi kepada Cerdas-

Sehat Online Shop.

Selanjutnya ditunjukkan dalam gambar 1. Tahapan penelitian.

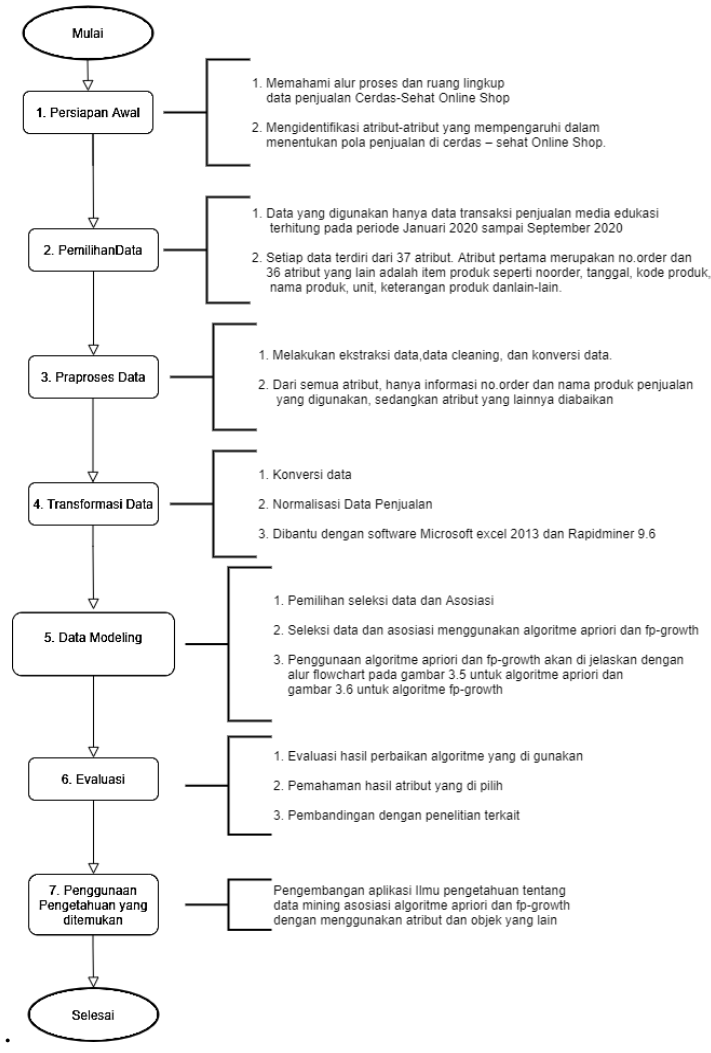

Sumber (Hasil Penelitian)

Gambar 1.

Tahapan Penelitian

Penentuan algoritme Apriori ditentukan kombinasi itemset yang memenuhi syarat minimum support dan confidence pada seluruh transaksi. Ditunjukkan pada gambar 2.

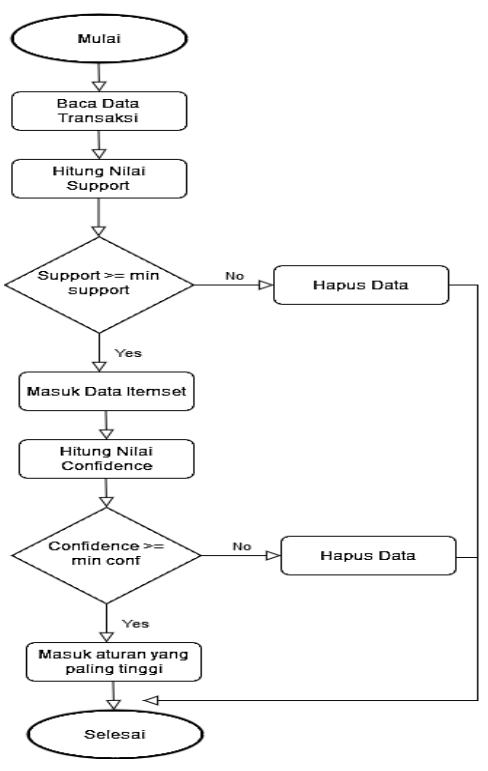

Sumber (Hasil Penelitian)

Gambar 2.

Tahapan algoritme Apriori

Penentuan algoritme FP-Growth menemukan frequent itemset yang sering muncul. Berikut 
flowchart algoritme FP-Growth ditunjukkan pada gambar 3.

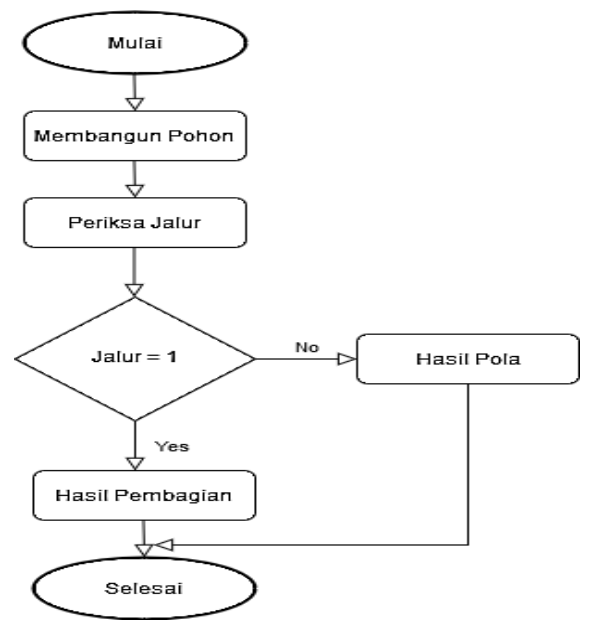

Sumber (Hasil Penelitian)

Gambar 3.

Tahapan algoritme FP-Growth

\section{HASIL DAN PEMBAHASAN}

\section{Persiapan Awal}

Hasil observasi dan wawancara di lapangan selama 3 bulan di Cerdas-Sehat Online Shop, maka peneliti memberikan analisa bahwa data penjualan selama ini tidak tersusun dengan baik sehingga data penjualan selama ini tidak dimanfaatkan dengan baik oleh perusahaan. Data tersebut hanya disimpan sebagai arsip atau pembukuan perusahaan dan tidak diketahui apa manfaat dari data-data yang ada tersebut.

\section{Pemilihan Data}

Data penjualan yang dipilih merupakan data penjualan media edukasi Cerdas-Sehat Online Shop dimulai pada 1 Januari 2020 sampai 30 September 2020. Berikut ini merupakan daftar data penjualan yang akan diteliti hanya 7 atribut yang ditampilkan pada tabel 1 .

Tabel 1

Data Transaksi Penjualan

Periode Januari - September 2020

\begin{tabular}{|c|l|c|c|}
\hline No & \multicolumn{1}{|c|}{ Nama Produk } & Unit & \multicolumn{1}{c|}{ Harga } \\
\hline 1 & $\begin{array}{l}\text { Mushaf Maqamat } \\
\text { For Kids }\end{array}$ & 7 & $1,799,000$ \\
\hline 2 & Hafizah Junior & 3 & 700,000 \\
\hline 3 & $\begin{array}{l}\text { Widya Wiyata } \\
\text { Pratama }\end{array}$ & 12 & $1,000,000$ \\
\hline 4 & $\begin{array}{l}\text { Widya Wiyata } \\
\text { Pratama }\end{array}$ & 12 & $1,000,000$ \\
\hline 5 & $\begin{array}{l}\text { Smart Pressure } \\
\text { Cooker }\end{array}$ & 7 & $1,970,000$ \\
\hline 6 & Hafizah Junior & 3 & 700,000 \\
\hline 7 & $\begin{array}{l}\text { Widya Wiyata } \\
\text { Pratama }\end{array}$ & 12 & $1,000,000$ \\
\hline
\end{tabular}

\begin{tabular}{|c|c|c|c|}
\hline No & Nama Produk & Unit & Harga \\
\hline 8 & $\begin{array}{l}\text { Widya Wiyata } \\
\text { Pratama }\end{array}$ & 12 & $1,000,000$ \\
\hline 9 & Smart Hafiz versi 2 & 8 & $2,374,000$ \\
\hline 10 & Smart Hafiz versi 2 & 8 & $2,374,000$ \\
\hline 11 & Smart Hafiz versi 2 & 8 & $2,374,000$ \\
\hline 12 & Smart Hafiz versi 2 & 8 & $2,474,000$ \\
\hline 13 & Hafizah Junior & 3 & 750,000 \\
\hline 14 & Smart Hafiz versi 2 & 8 & $2,299,000$ \\
\hline 15 & Smart Hafiz versi 2 & 8 & $2,299,000$ \\
\hline 16 & Smart Hafiz versi 2 & 8 & $2,299,000$ \\
\hline 17 & Smart Hafiz versi 2 & 8 & $2,299,000$ \\
\hline 18 & Smart Blender & 5 & $1,280,000$ \\
\hline 19 & Smart Hafiz versi 2 & 8 & $2,299,000$ \\
\hline 20 & Alhafiz + Pen & 5 & $1,300,000$ \\
\hline$\cdots$ & $\cdots$ & $\cdots$ & $\cdots$ \\
\hline 490 & Food Processor & 8 & $2,180,000$ \\
\hline 491 & Smart Hafiz versi 2 & 8 & $2,299,000$ \\
\hline 492 & Smart Hafiz versi 2 & 8 & $2,299,000$ \\
\hline 493 & Hafizah Junior & 3 & 750,000 \\
\hline 494 & Savra Towel & 1 & 149,900 \\
\hline 495 & Savra Towel & 1 & 149,900 \\
\hline 496 & Super Hafiz & 5 & 400,000 \\
\hline 497 & Super Hafiz & 5 & 400,000 \\
\hline 498 & Bumbu Javara & 1 & 66,000 \\
\hline
\end{tabular}

Sumber : Data Penjualan Cerdas-Sehat Online Shop

\section{Praproses Data}

Tahap dalam menganalisa data dengan algoritme Apriori dan FP-Growth pada data penjualan dimulai dengan menyeleksi dan membersihkan data-data yang akan dianalisis, kemudian dicari semua jenis itemset produk yang ada didalam transaksi penjualan. Selanjutnya dicari jumlah setiap itemset yang ada pada transaksi penjualan. Pada tabel 2 merupakan data penjualan yang sudah diberi kode produk agar memudahkan dalam menghitung. 
Tabel 4.2

Data Kode Produk

\begin{tabular}{|c|l|l|}
\hline No & \multicolumn{1}{|c|}{ Nama Produk } & \multicolumn{1}{|c|}{ Kode Produk } \\
\hline 1 & Alhafiz + Pen & AR1 \\
\hline 2 & Baby Rattle & AR2 \\
\hline 3 & Black Luxury & AR3 \\
\hline 4 & Blue Safir Swiden & AR4 \\
\hline 5 & Bougenville Set & AR5 \\
\hline 6 & Built In Hob & AR6 \\
\hline 7 & Bumbu Javara & AR7 \\
\hline 8 & Calliandra & AR8 \\
\hline 9 & $\begin{array}{l}\text { CCO, Madu, Sea } \\
\text { Salt }\end{array}$ & AR9 \\
\hline 10 & Chopping Board & AR10 \\
\hline$\ldots$ & $\ldots$ & $\ldots$ \\
\hline 54 & $\begin{array}{l}\text { Widya Wiyata } \\
\text { Pratama }\end{array}$ & AR54 \\
\hline
\end{tabular}

Sumber : Data produk Cerdas-Sehat Online Shop

Berdasarkan data awal penjualan dan data kode produk tersebut, maka yang akan dilakukan selanjutnya adalah pemilihan atribut-atribut yang mewakili dalam mencari aktivitas pola penjualan selama bulan januari 2020 sampai bulan September 2020. Atribut yang dibutuhkan hanya 2 atribut yaitu no.order dan nama produk. Daftar pola penjualan nama produk berdasarkan no.order pada tabel 3 .

Tabel 3

Pola Transaksi Penjualan

\begin{tabular}{|c|l|}
\hline No & \multicolumn{1}{|c|}{ Barang yang dibeli } \\
\hline 1 & $\begin{array}{l}\text { AR30, AR18, AR54, AR48, } \\
\text { AR47 }\end{array}$ \\
\hline 2 & AR47, AR18, AR44, AR1 \\
\hline 3 & $\begin{array}{l}\text { AR46, AR30, AR18, AR47, } \\
\text { AR25 }\end{array}$ \\
\hline 4 & AR47 \\
\hline 5 & $\begin{array}{l}\text { AR18, AR17, AR32, AR47, } \\
\text { AR46, AR54 }\end{array}$ \\
\hline 6 & $\begin{array}{l}\text { AR46, AR47, AR37, AR53, } \\
\text { AR29, AR26, AR45, AR30 }\end{array}$ \\
\hline 7 & AR30, AR47 \\
\hline 8 & AR47, AR49, AR17, AR8 \\
\hline 10 & $\begin{array}{l}\text { AR31, AR47, AR30, AR32, } \\
\text { AR46, AR2 }\end{array}$ \\
\hline$\ldots$ & $\ldots$ \\
\hline 56 & $\begin{array}{l}\text { AR47, AR18, AR41, AR53, } \\
\text { AR7 }\end{array}$ \\
\hline
\end{tabular}

Transformasi Data
Setelah pola penjualan terbentuk, selanjutnya dilakukan konversi data. Nilai 1 merupakan produk yang dibeli oleh customer. Nilai 0 merupakan produk yang tidak dibeli oleh customer. Perhitungan konversi data akan dibantu dengan menggunakan aplikasi Microsoft excel 2013. Daftar hasil konversi data ditampilkan di tabel 4.4. Untuk menampilkan semua kode produk dan transaksi akan ditampilkan pada daftar lampiran.

Tabel 4

Konversi Data

\begin{tabular}{|c|r|r|r|r|r|}
\hline No & \multicolumn{1}{|c|}{ AR1 } & \multicolumn{1}{|c|}{ AR2 } & \multicolumn{1}{|c|}{ AR3 } & $\ldots$ & AR54 \\
\hline 1 & 0 & 0 & 0 & $\ldots$ & 1 \\
\hline 2 & 1 & 0 & 0 & $\ldots$ & 0 \\
\hline 3 & 0 & 0 & 0 & $\ldots$ & 0 \\
\hline 4 & 0 & 0 & 0 & $\ldots$ & 0 \\
\hline 5 & 0 & 0 & 0 & $\ldots$ & 1 \\
\hline 6 & 0 & 0 & 0 & $\ldots$ & 0 \\
\hline 7 & 0 & 0 & 0 & $\ldots$ & 0 \\
\hline 8 & 0 & 0 & 0 & $\ldots$ & 0 \\
\hline 9 & 0 & 0 & 0 & $\ldots$ & 0 \\
\hline 10 & 0 & 1 & 0 & $\ldots$ & 0 \\
\hline 11 & 0 & 0 & 0 & $\ldots$ & 0 \\
\hline 12 & 0 & 0 & 0 & $\ldots$ & 0 \\
\hline$\ldots$ & $\ldots$ & $\ldots$ & $\ldots$ & $\ldots$ & $\ldots$ \\
\hline 56 & 0 & 0 & 0 & $\ldots$ & 0 \\
\hline
\end{tabular}

\section{Data Modeling}

Hasil data konvesi akan diseleksi dalam tahapan modeling dengan menggunakan assosiasi algoritme Apriori dan FP-Growth. Data modeling yang pertama dengan menggunakan algortime Apriori untuk mencari nilai minimum support dan nilai minimum confidence, selanjutnya data modelling yang kedua dengan perhitungan itemset yang sering muncul menggunakan algortime FP-Growth.

Pada tahapan algoritme Apriori untuk menghitung nilai kebenaran dengan cara mencari nilai minimum support dan nilai minimum confidence, Perhitungannya dibantu dengan menggunakan software rapidminer versi 9.6. Berikut hasil minimum support 0,1 dan minimum confidence 0,5 pada tabel 4 untuk 1 itemset dan tabel 5 untuk 2 itemset.

Tabel 5

Min support $10 \% 1$ itemset

\begin{tabular}{|c|c|c|}
\hline Kode & Jumlah & Support \\
\hline AR6 & 6 & $11 \%$ \\
\hline AR11 & 13 & $23 \%$ \\
\hline AR12 & 6 & $11 \%$ \\
\hline AR13 & 13 & $23 \%$ \\
\hline AR14 & 6 & $11 \%$ \\
\hline
\end{tabular}




\begin{tabular}{|c|c|c|}
\hline Kode & Jumlah & Support \\
\hline AR15 & 17 & $30 \%$ \\
\hline AR18 & 13 & $23 \%$ \\
\hline AR26 & 8 & $14 \%$ \\
\hline AR29 & 14 & $25 \%$ \\
\hline AR30 & 16 & $29 \%$ \\
\hline AR32 & 8 & $14 \%$ \\
\hline AR33 & 6 & $11 \%$ \\
\hline AR45 & 17 & $30 \%$ \\
\hline AR46 & 20 & $36 \%$ \\
\hline AR47 & 41 & $73 \%$ \\
\hline AR48 & 13 & $23 \%$ \\
\hline AR51 & 9 & $16 \%$ \\
\hline AR53 & 11 & $20 \%$ \\
\hline
\end{tabular}

Tabel 6

Min support $10 \% 2$ itemset

\begin{tabular}{|c|c|c|}
\hline Kode & jumlah & Support \\
\hline AR11-AR15 & 7 & $13 \%$ \\
\hline AR11-AR46 & 8 & $14 \%$ \\
\hline AR11-AR47 & 6 & $11 \%$ \\
\hline AR12-AR46 & 6 & $11 \%$ \\
\hline AR13-AR47 & 6 & $11 \%$ \\
\hline AR15-AR29 & 6 & $11 \%$ \\
\hline AR15-AR45 & 6 & $11 \%$ \\
\hline AR15-AR46 & 6 & $11 \%$ \\
\hline AR15-AR47 & 8 & $14 \%$ \\
\hline AR18-AR47 & 6 & $11 \%$ \\
\hline AR26-AR46 & 6 & $11 \%$ \\
\hline AR29-AR45 & 6 & $11 \%$ \\
\hline AR29-AR46 & 6 & $11 \%$ \\
\hline AR29-AR47 & 6 & $11 \%$ \\
\hline AR30-AR46 & 7 & $13 \%$ \\
\hline AR30-AR47 & 7 & $13 \%$ \\
\hline AR32-AR47 & 6 & $11 \%$ \\
\hline AR45-AR47 & 8 & $14 \%$ \\
\hline AR46-AR47 & 9 & $16 \%$ \\
\hline AR46-AR53 & 7 & $13 \%$ \\
\hline AR47-AR48 & 6 & $11 \%$ \\
\hline
\end{tabular}

Berdasarkan calon aturan asosiasi, maka yang memenuhi minimum confidence $50 \%$ dapat dilihat pada tabel 7.

Tabel 7

Aturan Asosiasi Final

\begin{tabular}{|c|l|c|}
\hline No & \multicolumn{1}{|c|}{ Kode } & Confidence \\
\hline 1 & $\begin{array}{l}\text { Jika menjual AR12 } \\
\text { maka akan menjual } \\
\text { AR46 }\end{array}$ & $100 \%$ \\
\hline 2 & $\begin{array}{l}\text { Jika menjual AR26 } \\
\text { maka akan menjual } \\
\text { AR46 }\end{array}$ & $75 \%$ \\
\hline
\end{tabular}

\begin{tabular}{|c|l|c|}
\hline No & \multicolumn{1}{|c|}{ Kode } & Confidence \\
\hline 3 & $\begin{array}{l}\text { Jika menjual AR53 } \\
\text { maka akan menjual } \\
\text { AR46 }\end{array}$ & $64 \%$ \\
\hline 4 & $\begin{array}{l}\text { Jika menjual AR11 } \\
\text { maka akan menjual } \\
\text { AR46 }\end{array}$ & $62 \%$ \\
\hline 5 & $\begin{array}{l}\text { Jika menjual AR11 } \\
\text { maka akan menjual } \\
\text { AR15 }\end{array}$ & $54 \%$ \\
\hline
\end{tabular}

Pada algoritme FP-Growth tidak melakukan generate candidate tetapi menggunakan konsep pembentukan pohon yang disebut FP-Tree pada pencarian frequent itemsets. Dalam hal itu menyebabkan algoritme FPGrowth lebih cepat dari algoritme Apriori. Metode FP-Growth dibentuk dalam pembangkitan pohon, sebelum membentuk pohon tersebut harus mengkonversi data transaksi penjualan dalam bentuk tabular kemudian dapat menentukan frekuensi setiap kode barang dari keseluruhan transaksi yang ditunjukkan pada tabel 8 .

Tabel 8

Kode Produk Terlaris

\begin{tabular}{|c|c|}
\hline Kode & Jumlah \\
\hline AR47 & 41 \\
\hline AR46 & 20 \\
\hline AR15 & 17 \\
\hline AR45 & 17 \\
\hline AR30 & 16 \\
\hline AR29 & 14 \\
\hline AR11 & 13 \\
\hline AR13 & 13 \\
\hline AR18 & 13 \\
\hline AR48 & 13 \\
\hline
\end{tabular}

Berdasarkan tabel 7 menyatakan hasil filterisasi data transaksi tersebut dari 56 transaksi menjadi 49 transaksi. Ini disesuaikan terhadap 10 kode produk yang terlaris dari periode bulan Januari - September 2020, selanjutnya dari hasil filterisasi dibuat pembangkitan pohon. Pembangunan Pohon transaksi level 1 ditunjukan pada gambar 4 .

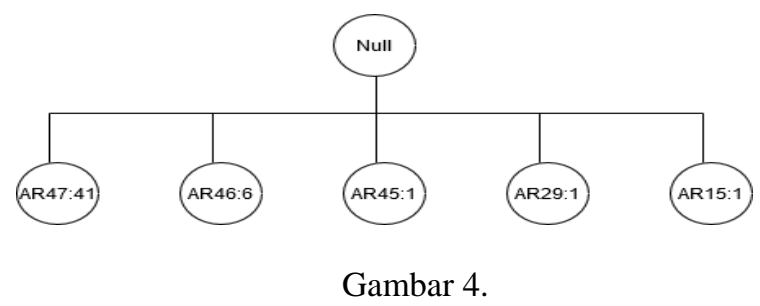

Hasil Pohon Transaksi level 1

1. Tahap pembangkitan conditional pattern base 
Mencari lintasan prefix dan pola akhiran melalui FP-Tree yang telah dibangun sebelumnya. Berikut tabel 9 untuk pembangkitan conditional pattern base.

Tabel 9

Conditional Pattern Base

\begin{tabular}{|c|c|c|}
\hline No & $\begin{array}{l}\text { Kode } \\
\text { Produk }\end{array}$ & Conditional Pattern Base \\
\hline 1 & AR48 & $\begin{array}{l}\{\{\text { AR47, AR45, AR30, } \\
\text { AR11, AR13: 1\}, \{AR47, } \\
\text { AR15, AR29, AR11, } \\
\text { AR13:1 },\{\text { AR47, AR46, } \\
\text { AR30, AR11, AR18:1\}, } \\
\text { \{AR47, AR30, } \\
\text { AR18:1\}, AR46, AR15, } \\
\text { AR13:1\}, \{AR47, } \\
\text { AR46:1 },\{\text { AR47:1 }\}\end{array}$ \\
\hline 2 & AR13 & $\begin{array}{l}\{\{\text { AR47, AR15, AR30, } \\
\text { AR29, AR11:1 }\},\{\text { AR47, } \\
\text { AR46, AR15, AR30, } \\
\text { AR11:1 },\{\text { AR47, AR15, } \\
\text { AR45, AR29:1 }\}\end{array}$ \\
\hline 3 & AR11 & $\begin{array}{l}\{\{\text { AR47, AR46, AR15, } \\
\text { AR45, AR29:1 }\},\{\text { AR47, } \\
\text { AR15, AR45, } \\
\text { AR30:1 }\},\{\text { AR47, AR46, } \\
\text { AR29:1 }\},\{\text { AR47, AR46, } \\
\text { AR15:1 }\},\{\text { AR47, AR46, } \\
\text { AR45:1 }\},\{\text { AR46, } \\
\text { AR15:1 }\},\{\text { AR46, } \\
\text { AR29:1 }\},\{\text { AR46, } \\
\text { AR29:1 }\},\{\text { AR46:1 }\}\end{array}$ \\
\hline 4 & AR18 & $\begin{array}{l}\text { \{AR47, AR46, AR15, } \\
\text { AR29:1 }\},\{\text { AR47, AR46, } \\
\text { AR30:1 }\},\{\text { AR47, } \\
\text { AR46:1 }\},\{\text { AR47, } \\
\text { AR15:1 }\},\{\text { AR47:1 }\},\{\text { AR47: } \\
\text { 1\},\{AR47:1 }\}\end{array}$ \\
\hline 5 & AR29 & $\begin{array}{l}\{\{\text { AR46, AR45, } \\
\text { AR30:1\},\{AR47, AR15, } \\
\text { AR30:1 }\},\{\text { AR47, AR45:1 }\} \\
\{\text { AR47:1\}, \{AR47:1 }\}\end{array}$ \\
\hline 6 & AR30 & $\begin{array}{l}\{\{\text { AR47, AR46, } \\
\text { AR31:1\}, }\{\text { AR47, AR48:1 }, \\
\{\text { AR47, AR46:1\}, } \\
\{\text { AR47:1\}, } \\
\{\text { AR46:1\},\{AR47:1\},\{AR47 } \\
: 1\}\}\end{array}$ \\
\hline 7 & AR45 & $\begin{array}{l}\{\{\text { AR47, } \\
\text { AR15:1 }\},\{\text { AR15:1 }\}\end{array}$ \\
\hline 8 & AR15 & $\{\{$ AR47:1 $\},\{$ AR47:1 $\}\}$ \\
\hline 9 & AR46 & $\{\{$ AR47:1 $\},\{$ AR47:1 $\}\}$ \\
\hline
\end{tabular}

2. Tahap pembangkitan conditional FP-Tree Pada tahap ini, setiap itemset pada setiap conditional pattern base akan dijumlahkan, selanjutnya setiap itemset yang mempunyai jumlah support count lebih besar yang akan dimunculkan. Berikut tabel 10 unutk pembangkitan conditional FP-Tree.
Tabel 10

Conditional Fp-Tree

\begin{tabular}{|c|c|c|}
\hline No & Kode Produk & Conditional FP-Tree \\
\hline 1 & AR48 & $\begin{array}{l}\{\text { AR47:7 }\},\{\text { AR11, } \\
\text { AR30, AR46, } \\
\text { AR13:3 }\} \\
\{\text { AR18,AR15:2 }\}\end{array}$ \\
\hline 2 & AR13 & $\begin{array}{l}\{\text { AR47, } \\
\text { AR15:3 }\},\{\text { AR30, } \\
\text { AR29, AR11:2 }\}\end{array}$ \\
\hline 3 & AR11 & $\begin{array}{l}\{\text { AR46:8 }\},\{\text { AR47:5 } \\
\},\{\text { AR15, } \\
\text { AR29:4 }\},\{\text { AR45:2 }\}\end{array}$ \\
\hline 4 & AR18 & $\begin{array}{l}\{\text { AR47:7 }\},\{\text { AR46:3 } \\
\},\{\text { AR15:2 }\}\end{array}$ \\
\hline 5 & AR29 & $\begin{array}{l}\{\text { AR47:3 }\},\{\text { AR45,A } \\
\text { R30:2 }\}\end{array}$ \\
\hline 6 & AR30 & $\begin{array}{l}\{\text { AR47:6 }\},\{\text { AR46:3 } \\
\}\end{array}$ \\
\hline 7 & AR45 & $\{\mathrm{AR} 15: 2\}$ \\
\hline 8 & AR15 & $\{$ AR47:2 $\}$ \\
\hline 9 & AR46 & $\{\mathrm{AR} 47: 2\}$ \\
\hline
\end{tabular}

3. Tahap pencarian frequent itemset

Jika conditional FP-Tree menghasilkan lintasan tunggal atau single path, maka diperoleh frequent itemset dengan kombinasi itemset untuk semua conditional FP-Tree. Jika bukan lintasan tunggal atau single path, maka diperoleh pembangkitan FP-Growth secara rekursif ditunjukkan pada tabel 11.

Tabel 11

Frequent Itemset

\begin{tabular}{|c|c|c|}
\hline No & Kode Produk & Frequent itemset \\
\hline 1 & AR48 & $\begin{array}{l}\{\text { AR47,AR48:7 }\},\{\text { AR1 } \\
\text { 1, AR30, AR46, AR13, } \\
\text { AR48:3 }, \\
\text { \{AR18,AR15, } \\
\text { AR48:2\} }\end{array}$ \\
\hline 2 & AR13 & $\begin{array}{l}\{\text { AR47, AR15, } \\
\text { AR13:3 }\},\{\text { AR30, } \\
\text { AR29, AR11, AR13 } \\
: 2\}\end{array}$ \\
\hline 3 & AR11 & $\begin{array}{l}\text { AAR46, } \\
\text { AR11:8\},\{AR47, } \\
\text { AR11:5\},\{AR15, } \\
\text { AR29, } \\
\text { AR11:4\},\{AR45, } \\
\text { AR11:2\} }\end{array}$ \\
\hline 4 & AR18 & $\begin{array}{l}\{\text { AR47, } \\
\text { AR18:7 }\},\{\text { AR46, } \\
\text { AR18:3 }\},\{\text { AR15, } \\
\text { AR18:2\} }\end{array}$ \\
\hline 5 & AR29 & $\begin{array}{l}\{\text { AR47, } \\
\text { AR29:3 }\},\{\text { AR45,AR30 } \\
\text {, AR29:2 }\}\end{array}$ \\
\hline
\end{tabular}




\begin{tabular}{|c|c|l|}
\hline No & Kode Produk & \multicolumn{1}{|c|}{ Frequent itemset } \\
\hline 6 & AR30 & $\begin{array}{l}\{\text { AR47, } \\
\text { AR30:6\}, }\{\text { AR46, } \\
\text { AR30:3 }\}\end{array}$ \\
\hline 7 & AR45 & $\{$ AR15, AR45:2 $\}$ \\
\hline 8 & AR15 & $\{$ AR47, AR15:2 $\}$ \\
\hline 9 & AR46 & $\{$ AR47, AR46:2 $\}$ \\
\hline
\end{tabular}

4. Aturan Asosiasi Final

Berdasarkan dari frequent itemset maka calon aturan asosiasi bisa diambil dari nilai support count yang lebih besar, ada 5 aturan asosiasi yang bisa dihasilkan. Berikut urutan sesuai nilai yang paling terbesar ditunjukkan pada tabel 12 .

Tabel 12

Aturan Asosiasi Final FP-Growth

\begin{tabular}{|c|l|c|}
\hline No & \multicolumn{1}{|c|}{ Kode } & $\begin{array}{c}\text { Support } \\
\text { Count }\end{array}$ \\
\hline 1 & $\begin{array}{l}\text { Jika menjual AR46 maka } \\
\text { akan menjual AR11 }\end{array}$ & 8 \\
\hline 2 & $\begin{array}{l}\text { Jika menjual AR47 maka } \\
\text { akan menjual AR48 }\end{array}$ & 7 \\
\hline 3 & $\begin{array}{l}\text { Jika menjual AR47 maka } \\
\text { akan menjual AR18 }\end{array}$ & 7 \\
\hline 4 & $\begin{array}{l}\text { Jika menjual AR47 maka } \\
\text { akan menjual AR30 }\end{array}$ & 6 \\
\hline 5 & $\begin{array}{l}\text { Jika menjual AR47 maka } \\
\text { akan menjual AR11 }\end{array}$ & 5 \\
\hline
\end{tabular}

\section{Evaluasi}

Untuk pembuktian kebenaran dari hasil analisa perhitungan algoritme Apriori dan FP-Growth dibutuhkan suatu proses pengujian kebenaran hasil pengolahan data yang sudah dilakukan secara manual yang sudah dikerjakan sebelumnya maka untuk proses pengujian bisa menggunakan alat software aplikasi seperti Rapidminer 9.6.

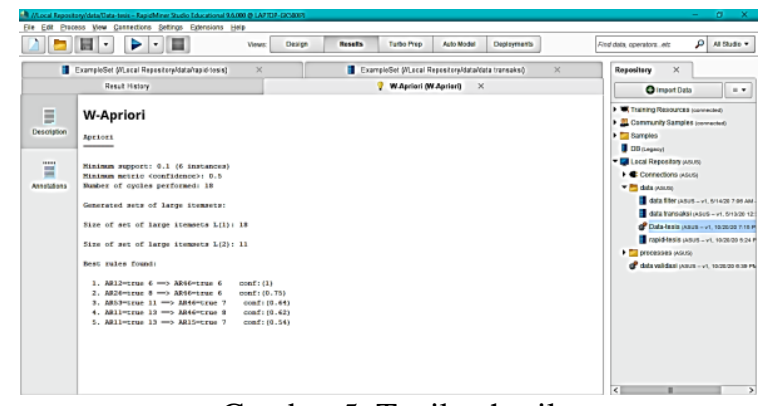

Gambar 5. Tapilan hasil

Dari gambar 5 menghasilkan hasil asosiasi final dengan aplikasi Rapidminer tenyata sesuai dengan hasil perhitungan manual.

\section{Penggunaan Pengetahuan}

Untuk algoritme Apriori menghasilkan tingkat keyakinan $100 \%$ dengan dukungan dari konsumen sebesar minimum support $10 \%$ dan minimum confidence 50\% sedangkan algoritme FP-Growth menghasilkan nilai support count 8 dengan dukungan minimum support count 2. Perhitungan tersebut memperbaiki hasil penelitian sebelumnya dengan tingkat keyakinan dari konsumen sebesar sebesar $70 \%$ sampai $90 \%$.

Aturan-aturan asosiasi yang dihasilkan menunjukkan:

1. Bahwa ada suatu barang yang harus dipertahankan atau tetap diperjualbelikan ditunjukkan tabel 13 dan ada juga barang yang harus tidak diperjualbelikan ditunjukkan pada tabel 14 karena pasar tidak mendukung atau konsumen tidak berminat lagi.

Tabel 13.

Barang yang harus dipertahankan

\begin{tabular}{|c|l|l|}
\hline No & \multicolumn{1}{|c|}{ Nama Produk } & \multicolumn{1}{c|}{ Kode } \\
\hline 1 & Built In Hob & AR6 \\
\hline 2 & Cooker Hood & AR11 \\
\hline 3 & Cordless Iron & AR12 \\
\hline 4 & Double Pan & AR13 \\
\hline 5 & Family Grill & AR14 \\
\hline 6 & Food Processor & AR15 \\
\hline 7 & Hafizah Junior & AR18 \\
\hline 8 & Littla Abid + Pen & AR26 \\
\hline 9 & Mixer & AR29 \\
\hline 10 & Mushaf Maqamaf for Kids & AR30 \\
\hline 11 & Mushaf For Woman & AR32 \\
\hline 12 & NS Cookware Set & AR33 \\
\hline 13 & Smart Cooker & AR45 \\
\hline 14 & Smart Hafiz versi 1 & AR46 \\
\hline 15 & Smart Hafiz versi 2 & AR47 \\
\hline 16 & Smart Pressure Cooker & AR48 \\
\hline 17 & SS Jumbo Cookware Set & AR51 \\
\hline 18 & Super Hafiz & AR53 \\
\hline
\end{tabular}

Tabel 14.

Barang yang tidak dipertahankan

\begin{tabular}{|r|l|l|}
\hline No & \multicolumn{1}{|c|}{ Nama Produk } & \multicolumn{1}{c|}{ Kode } \\
\hline 1 & Alhafiz + Pen & AR1 \\
\hline 2 & Baby Rattle & AR2 \\
\hline 3 & Black Luxury & AR3 \\
\hline 4 & Blue Safir Swiden & AR4 \\
\hline 5 & Bougenville Set & AR5 \\
\hline 6 & Bumbu Javara & AR7 \\
\hline 7 & Calliandra & AR8 \\
\hline 8 & CCO, Madu, Sea Salt & AR9 \\
\hline 9 & Chopping Board & AR10 \\
\hline 10 & Glassio Safety Timer & AR16 \\
\hline 11 & Hafiz Junior & AR17 \\
\hline 12 & Hafizdoll & AR19 \\
\hline 13 & Handuk Savra Terracota & AR20 \\
\hline
\end{tabular}




\begin{tabular}{|c|c|c|}
\hline No & Nama Produk & Kode \\
\hline 14 & Hijab Savra & AR21 \\
\hline 15 & Jam Ka'bah & AR23 \\
\hline 16 & Javara & AR24 \\
\hline 17 & Learning Math With Albert & AR25 \\
\hline 18 & Madu + VCO & AR27 \\
\hline 19 & Mie Vegan & AR28 \\
\hline 20 & $\begin{array}{l}\text { Muhammad Is My Hero + } \\
\text { Pen }\end{array}$ & AR31 \\
\hline 21 & Paket Estethic & AR34 \\
\hline 22 & Party Grill & AR35 \\
\hline 23 & Rice Cooker & AR36 \\
\hline 24 & Pen Little Abid & AR37 \\
\hline 25 & Pisau Blaumann & AR38 \\
\hline 26 & Pisau Swiden & AR39 \\
\hline 27 & Pressure Cooker & AR40 \\
\hline 28 & Savra Towel & AR41 \\
\hline 29 & Savra & AR42 \\
\hline 30 & Sea Salt & AR43 \\
\hline 31 & Smart Blender & AR44 \\
\hline 32 & Smart Ressa flash sale & AR49 \\
\hline 33 & Smart Watch & AR50 \\
\hline 34 & Super Cute Camera & AR52 \\
\hline 35 & Widya Wiyata Pratama & AR54 \\
\hline
\end{tabular}

2. Pengelola Cerdas-Sehat Online Shop diharapkan dapat menerapkan ilmu pengetahuan data mining dari hasil perhitungan tersebut untuk memprediksi target untuk penjualan yang akan datang dalam mempromosikan penjualan produk Cerdas-Sehat Online Shop.

3. Data-data yang tersimpan dapat dimanfaatkan kembali untuk digali sehingga bisa mendapatkan informasi dan pengetahuan baru bagi perusahaan.

Berikut barang-barang yang dapat dijual dengan cara bundling berdasarkan hasil pengetahuan ilmu data mining asosiasi dengan menggunakan algoritme Apriori dan FP-Growth.

1. Aturan asosiasi berdasarkan algoritme Apriori

a. Jika menjual Cordless Iron maka akan menjual Smart Hafiz versi 1

b. Jika menjual Madu + VCO maka akan menjual Smart Hafiz versi 1

c. Jika menjual Super Hafiz maka akan menjual Smart Hafiz versi 1

d. Jika menjual Cooker Hood maka akan menjual Smart Hafiz versi 1

e. Jika menjual Cooker Hood maka akan menjual Food Processor

2. Aturan asosiasi berdasarkan algoritme FP-Growth

a. Jika menjual Smart Hafiz versi 1 maka akan menjual Cooker Hood b. Jika menjual Smart Hafiz versi 2 maka akan menjual Hafizah Junior

c. Jika menjual Smart Hafiz versi 2 maka akan menjual Smart Pressure Cooker

d. Jika menjual Smart Hafiz versi 2 maka akan Muhammad Is My Hero + Pen

e. Jika menjual Smart Hafiz versi 2 maka akan menjual Cooker Hood

\section{KESIMPULAN}

Berdasarkan hasil analisa dan pengujian terhadap kajian penentuan pola penjualan media edukasi dengan menggunakan algoritme asosiasi Apriori dan FP-Growth (studi kasus : Cerdas-Sehat Online Shop) maka dengan menggunakan langkah-langkah algoritme Apriori dari tahap pemilihan sampai evaluasi berdasarkan data transaksi penjualan media edukasi untuk menentukan pola penjualan menghasilkan 5 pola aturan asosiasi minimum support sebesar $10 \%$ dan minimum confidence sebesar 50\% menghasilkan nilai confidence tertinggi yaitu $100 \%$, sedangkan algoritme FP- Growth menghasilkan 5 pola aturan asosiasi dengan minimum support count 2 menghasilkan nilai support count tertinggi yaitu 8. Dan juga menggunakan 2 atribut yaitu no.order dan kode produk dapat menemukan kecenderungan pola kombinasi antar itemset sehingga dapat dijadikan informasi yang sangat penting dalam pengambilan keputusan yang berguna untuk mempersiapkan jenis stok barang apa yang diperlukan kedepanya bagi penjualan di CerdasSehat Online Shop.

\section{REFERENSI}

Anggraeni, S., Iha, M. A., Erawati, W., \& Khairunnas, S. (2019). Analysis of Sales by Using Apriori and FP- Growth at PT . Panca Putra Solusindo, 3(2), 41-47.

Bee, T. A. (2015). Ebook Distributor, 1-35.

Chailes, A., Hermawan, A., \& Kurnaedi, D. (2020). Penerapan Metode Data Mining Untuk Menentukan Pola Pembelian Dengan Menggunakan Algoritma. JURNAL ALGOR, 2, $1-8$.

Chauhan, R., \& Kaur, H. (2017). Predictive Analytics and Data Mining. https://doi.org/10.4018/9781-4666-4940-8.ch004

Faisal. (2018). Penerapan Metode Association Rule Mining Untuk Analisis Dan Implementasi Teknik Data Mining Dalam Memprediksi. INSTEK, 3, 151-160.

Harianto, \& Eddy, H. (2016). Analisa data transaksi penjualan barang menggunakan algoritme Apriori dan FP-Growth. Jnanaloka.

Henando, L. (2019). ALGORITMA APRIORI DAN FP-GROWTH UNTUK ANALISA PERBANDINGAN DATA PENJUALAN LEPTOP BERDASARKAN MERK YANG DIMINATI KONSUMEN (STUDI KASUS : INDOCOMPUTER PAYAKUMBUH). $J$ - 
Click, 6(2), 201-207.

Junianto, E., \& Rachman, R. (2020). IJCIT (Indonesian Journal on Computer and Information Technology) Penerapan Data Mining Metode Apriori dan FP-Tree Pada Penjualan Media Edukasi (Studi Kasus : Oisha Smartkids). IJCIT (Indonesian Journal on Computer and Information Technology), 5(2), 117-125.

Putra, A. C., \& Habibi, M. (2019). ANALISIS ASOSIASI PADA TRANSAKSI PENJUALAN DARING MENGGUNAKAN ALGORITMA APRIORI DAN FP-GROWTH Abstrak. TEKNOMATIKA ISSN: 1979-7656, Vol. 11, N, 119-129.

Witten, I. H., Frank, E., \& Hall, M. a. (2019). Data Mining: Practical Machine Learning Tools and Techniques (Google eBook). Complementary literature None. Retrieved from http://books.google.com/books?id=bDtLM8C ODsQC\&pgis $=1$
Yanson, R. (2016). Improving e-learning outcomes through purposeful peer interactions: Three helpful recommendations to ensure success. Development and Learning in Organizations, 28(3), 10-12. https://doi.org/10.1108/DLO-112013-0083

Zurada, J. M. (2019). Data mining with computational intelligence. IEEE Transactions on Neural Networks (Vol. 17). https://doi.org/10.1109/TNN.2006.875965

\section{PROFIL PENULIS}

Penulis bernama Rizal Rachman menyukai bidang minat ilmu data mining dan Sistem Informasi 